\title{
UTILIZATION OF CHICKEN FEATHER BIOMASS AS METAL ZINC ADSORBENT $\left(\mathbf{Z n}^{2+}\right)$
}

\author{
Djama'an Noer Hidayat ${ }^{1,3}$, Maming ${ }^{1,3^{*}}$, Syarifuddin Liong ${ }^{2,3}$ \\ ${ }^{1}$ Inorganic Chemistry Laboratory, Department of Chemistry, Faculty of Mathematics and Natural \\ Sciences, Hasanuddin University \\ ${ }^{2}$ Analytical Laboratory, Department of Chemistry, Faculty of Mathematics and Natural Sciences, \\ Hasanuddin University \\ ${ }^{3}$ Department of Chemistry, Faculty of Mathematics and Natural Sciences, Hasanuddin University, \\ Perintis Kemerdekaan Street KM 10, Tamalanrea Makasssar, Indonesia 90245 \\ *Corresponding author: maming.gappa@gmail.com
}

\begin{abstract}
Abstrak. Bulu ayam merupakan limbah yang dapat dimanfaatkan keberadaannya sebagai alternatif adsorben yang dapat digunakan dalam mengatasi pencemaran lingkungan di perairan yang mengandung polutan logam berat khususnya pada logam ion Zn(II), Biomassa Bulu Ayam menggunakan $\mathrm{NaOH}$ dan $\mathrm{Na}_{2} \mathrm{SO}_{3}$ sebagai aktivasi adsorben dan dibuktikan dengan menggunakan spektrofotometer FTIR. Adsorben logam ion Zn(II) oleh Biomassa bulu ayam telah dilakukan pengaruh terhadap variasi $\mathrm{pH}$ larutan, massa adsorben, waktu kontak, dan konsentrasi terhadap biomassa bulu ayam. Metode yang digunakan adalah metode "batch" dan konsentrasi logam ion $\mathrm{Zn}$ (II) diukur dengan spektrofotometer serapan atom (SSA). Variasi Optimal yang telah dicapai pada kondisi $\mathrm{pH}$ 6, massa adsroben 0,7 gram, waktu kontak selama 80 menit, dan konsentrasi optimal pada $100 \mathrm{ppm}$ dengan penyerapan logam ion $\mathrm{Zn}$ (II) terhadap biomassa bulu ayam sebesar $6,04 \mathrm{mg} / \mathrm{g}$. Adsorben logam ion Zn(II) menggunakan biomassa bulu ayam lebih sesuai dengan model isotermal Langmuir dengan nilai kapasitas adsorpsi $\left(\mathrm{Q}_{\mathrm{o}}\right)$ adalah $6,45 \mathrm{mg} / \mathrm{g}$.
\end{abstract}

Kata kunci: Adsorben, Biomassa bulu ayam, SSA, Zn(II)

\begin{abstract}
Chicken feather is a waste that can be used as an alternative to adsorbents that can be used to overcome environmental pollution in waters containing heavy metal pollutants, especially on metal $\mathrm{Zn}$ (II) ions, Biomass Chicken Feathers using $\mathrm{NaOH}$ and $\mathrm{Na} 2 \mathrm{SO} 3$ as adsorbent activation and proven using FTIR spectrophotometer. The metal adsorbent of Zn (II) ion by chicken feather biomass has been influenced to the variation of $\mathrm{pH}$ of the solution, mass of adsorbent, contact time, and concentration of chicken feather biomass. The method used is the method of "batch" and the metal concentration of Zn (II) ions measured by an atomic absorption spectrophotometer (AAS). Optimal variations that have been achieved under conditions of $\mathrm{pH} 6$, adsorbent mass 0.7 gram, contact time for 80 minutes, and optimal concentration at $100 \mathrm{ppm}$ with absorption of $\mathrm{Zn}$ (II) metal on chicken feather biomass of $6.04 \mathrm{mg} / \mathrm{g}$. The metal adsorbent $\mathrm{Zn}$ (II) using chicken feather biomass is more in line with the Langmuir isothermal model with an adsorption capacity $\left(\mathrm{Q}_{\mathrm{o}}\right)$ value of $6.45 \mathrm{mg} / \mathrm{g}$.
\end{abstract}

Keywords: Adsorbent, Chicken feather biomass, SSA, Zn (II) 


\section{INTRODUCTION}

Environmental pollution by heavy metals is a quite serious problem along with the increasing technological advances including the development of industrial activities, agriculture, and the demand for various community needs that are increasing every year. The dominant environmental pollution at present is heavy metal waste originating from industrial activities (Wagini and sukaryono, 2008).

Heavy metals are widely used in industry because they can deliver electricity and heat and can form metal alloys with other metals. In addition, developments in the industrial sector will certainly be followed by the increase in heavy metals contained in the waste produced. The process of industrial activity can cause the environment to be increasingly polluted with the heavy metal content in the waste (Ceribasi and Yetis, 2001).

One of the heavy metals which is a pollutant and needs to be lowered in concentration until it meets the quality standard requirements of wastewater in waters is $\mathrm{Zn}$ metal. $\mathrm{Zn}$ specimens are widely used in the metal coating, battery, leather tanning, paint and textile industries. Based on the decision of the State Minister of Environment Number: KEP-03 / MENLH / 2010 stated that the quality standard of wastewater for industrial zones for maximum parameters of zinc metal is $10 \mathrm{mg} / \mathrm{L}$. Excessive amounts of $\mathrm{Zn}$ are toxic. $\mathrm{Zn}$ poison power can inhibit the work of enzymes, so that the body's metabolic processes are cut off. Furthermore, this heavy metal can cause allergies, mutagens, teratogens or carcinogens for humans (Angga and Evan, 1995).
Several methods have been used to reduce $\mathrm{Zn}$ levels in liquid waste including using adsorption. Researchers have now developed a lot of adsorption application technology using biomaterials from chicken feathers to reduce the levels of heavy metals from industrial waste. Chicken feather biomass has been used to reduce copper levels of $400 \mathrm{mg} / \mathrm{L}$ in determining the surface area of the adsorbent with a maximum contact time of 80 minutes, $\mathrm{pH}$ of solution 7 with a surface area of $71.5 \mathrm{~m}^{2} / \mathrm{g}$ (Ni'mah and Ulfin, 2007). The effect of ascorbic acid addition on chicken feathers as adsobern on the absorption ability of cadmium metal ions $\left(\mathrm{Cd}^{2+}\right)$ in solution showed a contact time of 40 minutes, $\mathrm{pH} \mathrm{7,} \mathrm{and} \mathrm{adsorption} \mathrm{capacity}$ of $26.32 \mathrm{mg} / \mathrm{g}$ (Khumairoh, 2007). In 2008 Rosa et al. Conducted a study to reduce levels of lead heavy metal using chicken feather as an adsorbent indicating that maximum uptake occurred at $\mathrm{pH} 5$ with adsorption capacity reaching $8.3 \mathrm{mg} / \mathrm{g}$.

Chicken Feather is an abundant amount of waste from chicken slaughterhouses (RPA) as the chicken population increases and demand is demanded by the community. Chicken feathers have not been widely used until now and most of them are thrown away, so that they also pollute the surrounding environment.

Chicken feathers can be used as an adsorbent against heavy metals from the waters because they contain fiber or keratin proteins, namely: crude protein $(80.00 \%)$, crude fat $(7.79 \%)$ and crude fiber $(0.88 \%)$ (Elfia et al, 2002 ) Keratin is a fiber protein that is rich in sulfur and cysteine, so that in the structure of cysteine there are amino acids containing functional groups in the 
form of carboxylates, amines and sulfihidril side chains which are believed to provide polyelectrolyte properties so they can act as ion exchangers (Tan, 1985).

Activation with an alkaline solution, which is a mixture of $\mathrm{NaOH} / \mathrm{Na}_{2} \mathrm{SO}_{3}$, can increase the adsorption capacity of chicken feathers against heavy metal wastes in solution to $97.63 \%$ with a mixture of $0.1 \mathrm{~N}$ and stirring time of 30 minutes to activate chicken feather biomass with alkaline solution ( Setyorini, 2006).

Thus related to this research, researchers have managed chicken feather waste which has been activated using $\mathrm{NaOH} / \mathrm{Na}_{2} \mathrm{SO}_{3}$ solution as an adsorbent that can be used to overcome environmental quality degradation due to contamination of heavy metal ions, especially $\mathrm{Zn}^{2+}$ metal ions using the bacth method.

\section{MATERIAL AND METHODS Materials}

The materials used in this study were $\mathrm{NaOH}, \mathrm{Na}_{2} \mathrm{SO}_{3}, \mathrm{HNO}_{3}, \mathrm{HCl}$, Diethyl ether, Aquabides, $\mathrm{ZnSO}_{4} .2 \mathrm{H}_{2} \mathrm{O}$, Filter paper whatman no. 42 , tissue roll and plastic wrap.

\section{Tools}

The tools used in this study are 30 mesh sieve, Buchner Funnel, Erlenmeyer, Chemical Glass, Analytical Balance, Drop Pipette, Measuring Flask, Volume Pipette, Mump Pipette, Bulb, Magnetic Stirrer, Oven, $\mathrm{pH}$ Meter, Atomic Absorption Spectrophotometry (SSA), FT-IR Spectrometer.

\section{Procedures}

\section{Making Chicken Feather Biomass}

Broiller chicken feather is washed with detergent and rinsed with water several times until the foam and dirt are gone, then dried in the sun to dry until it doesn't smell fishy. After drying, the chicken feathers are cut into small pieces, then ground until smooth using a grinder, then crushed using iron mortar until smooth like flour, sifted using a 30 mesh sieve, then soaked with diethyl ether for 20 minutes, then filtered using a Buchner funnel. The residue obtained is dried in an oven at a temperature of $40^{\circ} \mathrm{C}$ to a constant weight so that the biomass is ready for use (Iksan, 2011).

\section{Activating Chicken Feathers with Alkali Solution}

Biomass was taken as much as 35 grams and activated by soaking with $0.1 \mathrm{~N}$ $\mathrm{NaOH}$ as much as $100 \mathrm{~mL}$, stirring for 20 minutes and filtered. Then soaked again with $0.1 \mathrm{~N} \mathrm{Na}_{2} \mathrm{SO}_{3}$ as much as $100 \mathrm{~mL}$, stirring for 20 minutes. Then, filtered using a Buchner funnel. The residue obtained was dried in an oven at $50 \mathrm{o} \mathrm{C}$ to obtain activated biomass of chicken feathers that are ready for use. The characteristics of this biomass were carried out using an FT-IR spectrometer (Ketaren, 1986).

\section{Making Standard Solutions}

Carefully weighed 2,741 mg $\mathrm{ZnSO}_{4} .2 \mathrm{H}_{2} \mathrm{O}$ then dissolved with aquabides into a beaker, added a few drops of $\mathrm{HNO}_{3} 1 \mathrm{M}$ and then put into a $1000 \mathrm{~mL}$ volumetric flask and added aquides to the boundary mark and homogenized. 


\section{Determination} Adsorption pH

Fifty $\mathrm{mL}$ of Zinc (Zn) $250 \mathrm{ppm}$

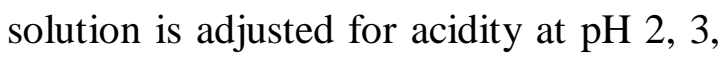
4, 5, 6 and 7 by using $\mathrm{NaOH} 0,1 \mathrm{~N} / \mathrm{HCl}$ $0.1 \mathrm{~N}$ then 0.5 gram of chicken feather is added and stirred above magnetic stirrer for 30 minutes. filtered, then piped $1 \mathrm{~mL}$ each, put into a $50 \mathrm{~mL}$ volumetric flask and impregnated with $0.01 \mathrm{~N} \mathrm{HNO}_{3}$ and homogenized and then analyzed by SSA at $\lambda 213.9 \mathrm{~nm}$.

\section{Determination of Optimum Adsorption Adsorbent Mass}

Each chicken feather biomass is weighed as much as $0.1 ; 0.3 ; 0.5$; and 0.7 gram then put in $50 \mathrm{~mL}$ of Zinc ( $\mathrm{Zn}$ ) solution of $250 \mathrm{ppm}$ with optimum $\mathrm{pH}$ from the results of determining the optimum $\mathrm{pH}$ of the adsorption and stirring with a magnetic stirrer for 30 minutes. The solution was filtered, then piped $1 \mathrm{~mL}$ each, put into a $50 \mathrm{~mL}$ volumetric flask and impregnated with $0.01 \quad \mathrm{~N} \quad \mathrm{HNO}_{3}$ and homogenized and then analyzed by SSA at $\lambda 213.9 \mathrm{~nm}$.

\section{Determination of Optimum Contact Time Adsorption}

Chicken feather biomass was weighed according to the results of optimum adsorption adsorption mass then put in $50 \mathrm{~mL}$ zinc solution with a concentration of $250 \mathrm{ppm}$ and at optimum $\mathrm{pH}$ the optimum $\mathrm{pH}$ of adsorption was then stirred with a magnetic stirrer with a time variation of $20,40,60,80,100$, and 120 minutes, filtered, then piped $1 \mathrm{~mL}$ each, put into a $50 \mathrm{~mL}$ volumetric flask and impregnated with $0.01 \mathrm{~N} \mathrm{HNO}_{3}$ and homogenized and then analyzed by SSA at $\lambda 213.9 \mathrm{~nm}$.

\section{Determination of Optimum Adsorption Concentration}

Fifty $\mathrm{ml}$ of zinc solution with variations in concentrations of $20 \mathrm{ppm}, 40$ ppm, 60 ppm, 80 ppm, 100 ppm, 150 ppm, $200 \mathrm{ppm}$ and $250 \mathrm{ppm}$ with optimum $\mathrm{pH}$ results of optimum adsorption $\mathrm{pH}$ determination, and enter chicken feather biomass for optimum mass yield Determination of the optimum adsorbent mass of adsorption into each solution and then stirred with a magnetic stirrer during optimum contact time for the adsorbent. The solution was filtered, then each was diluted and squeezed with $0.01 \mathrm{~N} \mathrm{HNO}_{3}$ on a $50 \mathrm{~mL}$ volumetric flask and then analyzed by SSA at $\lambda 213.9 \mathrm{~nm}$.

The $\mathrm{Zn}^{2+}$ concentration adsorbed for each treatment was calculated from:

Adsorbed concentration $=$ initial concentration - Final concentration

$$
C_{\text {adsorpsi }}=C_{\text {awal }}-C_{\text {akhir }}
$$

The amount of adsorbed metal ions (mg) per gram of adsorbent (chicken feather biomass) is determined using the equation:

$$
\mathrm{qe}=\frac{\left(C_{0}-C_{t}\right) V}{W}
$$

Information:

$\mathrm{qe}=$ zinc level adsorbed $(\mathrm{mg} / \mathrm{g})$

$\mathrm{C}_{0}=$ initial zinc concentration $(\mathrm{mg} / \mathrm{L})$

$\mathrm{C}_{\mathrm{t}}=$ final concentration of $\mathrm{zinc}(\mathrm{mg} / \mathrm{L})$

$\mathrm{V}=$ volume of solution (Liter)

$\mathrm{W}=$ weight of the adsorbent used (gram)

The adsorption capacity is calculated from the Langmuir equation $\left(\mathrm{C}_{\mathrm{e}} / \mathrm{q}_{\mathrm{e}}=1 / \mathrm{Q}_{\mathrm{ob}}+\right.$ $\mathrm{C}_{\mathrm{e}} / \mathrm{Q}_{\mathrm{o}}$ ) or the Freundlich equation $[\log (\mathrm{x}$ $/ \mathrm{m})=\log \mathrm{k}+1 / \mathrm{n}(\log \mathrm{C})$ by channeling $\mathrm{Ce} / \mathrm{qe}$ to $\mathrm{Ce}$ for the Langmuir equation or 
the Freundlich equation is obtained $\mathrm{k}$ value (adsorption capacity) and from the slope of the Langmuir equation can be obtained a Qo value that is related to adsorption capacity.

\section{RESULTS AND DISCUSSION FTIR Analysis of Chicken Feathers}

Changes in the biomass of dried chicken feathers are then activated by using $\mathrm{NaOH}$ and $\mathrm{Na}_{2} \mathrm{SO}_{3}$ to activate the protein group on chicken feathers, namely $\alpha$ keratin which contains cysteine so that it can absorb more optimally, so that the activation can be carried out perfectly. using an FT-IR spectrophotometer instrument. Each bond has a unique vibrational frequency so that infrared absorption can be used to identify groups present in a compound.

Changes in chicken feather biomass before (a) and after activation (b) appear in functional group analysis using FT-IR seen in Figure 5 that the structure shows the characteristics of the peptide bond absorption area (-CONH-), the vibrations in the bond are known as regions I-III amide uptake (Woejciechowska et al., 1999). The amide absorption area I shows the vibration stretching of the $\mathrm{C}=\mathrm{O}$ group that appears with contributions from $\mathrm{N}-\mathrm{H}$ bending and C-N stretching appearing at wave numbers $1600-1700 \mathrm{~cm}^{-1}$ (Sun et al., 2009). In chicken feather biomass before activation appears at wave number 1660 $\mathrm{cm}^{-1}$ while after activation appears at wave number $1645 \mathrm{~cm}^{-1}$. Amide II absorption area appears at wave numbers between $1335-1560 \mathrm{~cm}^{-1}$ derived from $\mathrm{NH}$ bending vibrations and stretching $\mathrm{CH}$, on chicken feathers before activation appears in the number Regions Amide III absorption appears at wave numbers around $1240 \mathrm{~cm}^{-}$ ${ }^{1}$ is the area produced from the combination of $\mathrm{CN}$ stretching and $\mathrm{NH}$ bending, with some influence from $\mathrm{CC}$ stretching vibrations and bending $\mathrm{C}=\mathrm{O}$ (Sun et al., 2009). wave $1526 \mathrm{~cm}^{-1}$ and after activation appear at wave number $1546 \mathrm{~cm}^{-1}$.
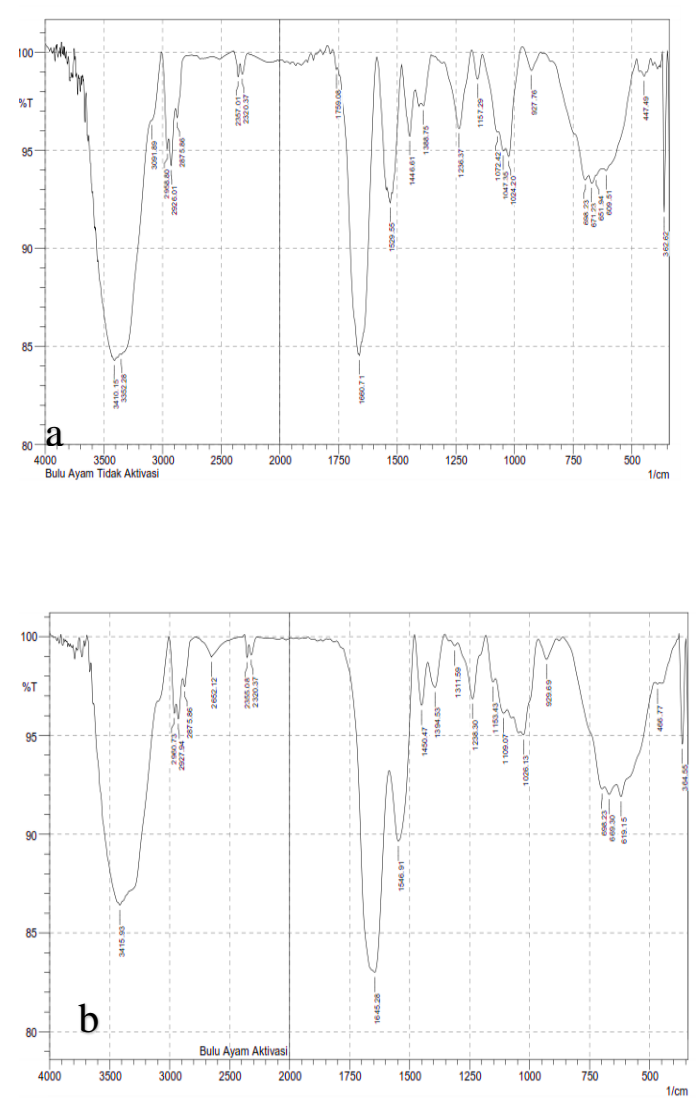

Figure 1. Results of FTIR Analysis on Chicken Feather Biomass (a) Before Activation and (b) After Activation

Chicken feathers before activation showed absorption peaks at $1236 \mathrm{~cm}^{-1}$ and $1238 \mathrm{~cm}^{-1}$ for activated chicken feathers with small peak shapes. Significant changes can be seen in amide in region IIII supported by the absorption area of keratin fibers appearing in waves $3416 \mathrm{~cm}^{-}$ 1 (Khosa et al., 2013), before activation does not show the closest wave number 
whereas after activation in chicken feather biomass shows numbers wave $3415.93 \mathrm{~cm}^{-}$ 1 .

The results of FT-IR analysis can be seen that before and after activation of the structure or component of chicken feather biomass shows results that are in accordance with the $\alpha$-keratin functional group because it shows absorption of the $\mathrm{C}-\mathrm{H}, \mathrm{C}-\mathrm{O}, \mathrm{N}-\mathrm{H}$ groups.

Research by Sun et al. (2009) states that there is an association between peaks at $1167 \mathrm{~cm}^{-1}$ and $1073 \mathrm{~cm}^{-1}$ against symmetrical and asymmetric stretching vibrations of the activator solution residues used in this case 1-butyl-3methylimidazolium chloride ([BMIM] $\mathrm{Cl}$ ), In the biomass of activated chicken feathers showed higher absorption peaks than biomass of feathers before activation and indicated a break in activated SS bonds in chicken feathers. It is also seen in this study, it is clear that the difference in absorption intensity in these two wave numbers from chicken feather biomass before activation and after activation. FTIR results after and before activation by chicken feather biomass are shown in Table 1.

Table 1. Characteristics of peptide bond uptake (-CONH-) indicated by amide I-III

\begin{tabular}{lccc}
\hline Functional group & \multicolumn{3}{c}{ Wavenumber $\left(\mathrm{cm}^{-1}\right)$} \\
\cline { 2 - 4 } & before & after & difference \\
\hline $\begin{array}{l}\text { Amide I : } \\
\text { Stretching vibration of C=O } \\
\text { group }\end{array}$ & 1660 & 1645 & -15 \\
\hline $\begin{array}{l}\text { Amide II : } \\
\text { Bending vibration of N-H } \\
\text { and Stretching C-H }\end{array}$ & 1526 & 1546 & 20 \\
\hline $\begin{array}{l}\text { Amide III : } \\
\text { Bending vibration C-N and } \\
\mathrm{N}-\mathrm{H}\end{array}$ & 1236 & 1238 & 2 \\
\hline
\end{tabular}

Results of Determination of Acidity (pH) Optimum Adsorption of Metal Zinc $\left(\mathrm{Zn}^{+2}\right)$ by Biomass Chicken Feathers

At this stage an acidity $(\mathrm{pH})$ optimization is carried out because the acidity in the solution can affect functional groups of adsorbent walls which can play an active role in absorbing heavy metals, besides that it affects the solubility of metal ions in solution, so acidity $(\mathrm{pH})$ is a parameter important in biosorption of metal ions in solution (Volesky, 1990). The condition of environmental $\mathrm{pH}$ is very influential on the ionization of the functional groups of amino acids making up proteins that will provide a place for binding to heavy metals (Wirahadikusuma, 2001).

Optimization of $\mathrm{pH}$ of the solution to the absorption of $\mathrm{Zn}^{2+}$ metal ion in this study was carried out with variations in $\mathrm{pH}$ of 2, 3, 4, 5, 6, 7, and 9. Seen in Figure 2 the relationship between $\mathrm{pH}$ and the amount of zinc absorbed by chicken feather biomass. 


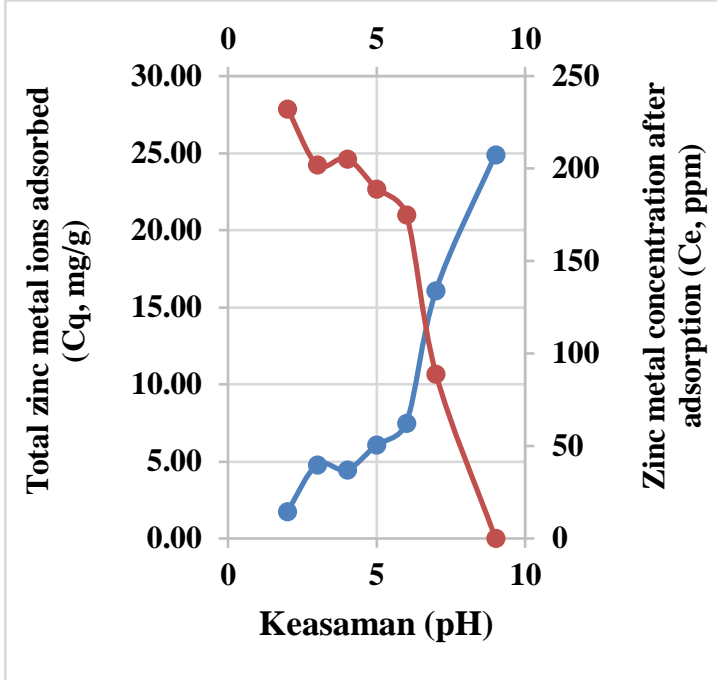

Figure 2. Relationship between $\mathrm{pH}$ and the amount of $\mathrm{Zn}^{2+}$ absorbed by Biomass Chicken Feathers.

At $\mathrm{pH} 2$ the number of ions adsorbed was $\left(\mathrm{C}_{\mathrm{q}}\right) \quad 1.75 \mathrm{mg} / \mathrm{g}$ with metal concentration after adsorption $\left(\mathrm{C}_{\mathrm{e}}\right) 232.43$ ppm and $\mathrm{pH} 3$ showed the number $\mathrm{Cq}$ of $4.79 \mathrm{mg} / \mathrm{g}$ and the metal concentration after adsorption $\left(\mathrm{C}_{\mathrm{e}}\right) 202 \mathrm{ppm}$ due to the process of forming a complex of biomass (cysteine) with metal ions generally accompanied by the release of hydrogen ions (protons). If the $\mathrm{pH}$ is low (acidic) then the metal is more likely to dissolve, thus causing a reduction in the ability of active cluster of biomass in binding metal ions.

In the condition of $\mathrm{pH} 3$ the adsorption of $\mathrm{Zn}^{2+}$ ions by biomass of chicken feathers tends to decrease, this is because it has been covered by a layer of zinc ion adsorbed. The $\mathrm{pH} 4$ condition above shows that the higher the $\mathrm{pH}$, the greater the adsorption. Nafie (2010) said that at low $\mathrm{pH}$ coverage and low biosorption occurs because of the presence of protons with high concentrations in solution. This proton competes with metal ions in the formation of bonds on the active side (functional group) on the surface of chicken feather adsorbent, so that the surface becomes saturated and cannot interact with other cations. This result is in accordance with previous research.

The optimum absorption of $\mathrm{Zn}^{2+}$ ions by chicken feather biomass occurred at $\mathrm{pH}$ 6 with the zinc metal concentration absorbed after adsorption $\left(\mathrm{C}_{\mathrm{e}}\right)$ of 189.14 ppm so that the amount of zinc ion adsorbed $\left(\mathrm{C}_{\mathrm{q}}\right)$ of $7.49 \mathrm{mg} / \mathrm{g}$ was related to this increase in $\mathrm{pH}$ means the number of protons is low. This causes a decrease in competition between protons and heavy metal ions, so that biosorption increases.

At pH 7 there was a decrease in the absorption of zinc by biomass of chicken feather $\mathrm{C}_{\mathrm{q}}$ of $16.09 \mathrm{mg} / \mathrm{g}$ with $\mathrm{C}_{\mathrm{e}}$ of 89.03 ppm and the condition of $\mathrm{pH} 9$ absorption that was read greater was $\mathrm{C}_{\mathrm{q}} 24.93 \mathrm{mg} / \mathrm{g}$ with the value of $\mathrm{C}_{\mathrm{e}}$ reaching $0.168 \mathrm{ppm}$. In Figure 2 it can be seen that the absorption is greater but the condition above $\mathrm{pH} 6$ occurs deposition on zinc metal to be white like gelatin due to the reaction between $\mathrm{OH}^{-}$and $\mathrm{Zn}^{2+}$ to $\mathrm{Zn}(\mathrm{OH})_{2} \downarrow$ so that before being absorbed by biomass, zinc metal already reacted first with the $-\mathrm{OH}$ group (Vogel, 1995).

Results of Determination of Optimum Mass Adsorption of Zinc Zinc $\mathrm{Zn}^{+2}$ Metal by Biomass Chicken Feathers

The mass determination of the adsorbent was carried out to determine the optimal condition of chicken feather biomass can work with certain mass variant conditions. It was said earlier that one of the factors that influenced the adsorption process was the small amount of mass of the adsorbent used in the adsorption process. At this stage a mass variation of chicken feather adsorbent was made of 0.1 ; 
$0.3 ; 0.5 ; 0.7$ gram, with a concentration of $250 \mathrm{ppm}$ in $50 \mathrm{~mL}$ at $\mathrm{pH} 6$.

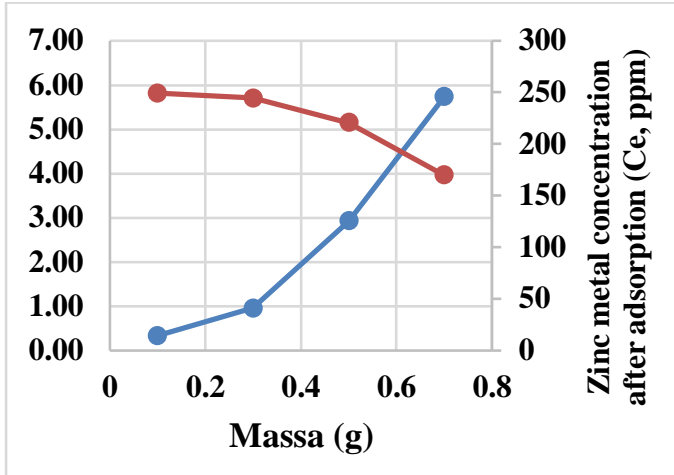

Figure 3. Relationship of Adsorbent Mass and Amount of $\mathrm{Zn}^{2+}$ adsorbed by Biomass of Chicken Feathers.

Increasing the number of adsorbents will expand the surface. The adsorption process depends on the number of collisions occurring between the particles of the adsorbate and the adsorbent. Effective collisions between particles will increase with increasing surface area. If the surface of the active group from the adsorbent becomes wider, the amount of metal $\mathrm{Zn}^{2+}$ ions absorbed in chicken feathers is increasing, as shown in Figure 3.

The amount of mass of the adsorbent also affects the amount of zinc absorbed. As much as $0.1 \mathrm{~g}$ of the adsorbent can absorb $\mathrm{C}_{\mathrm{q}}$ of $0.34 \mathrm{mg} / \mathrm{g}$ with $\mathrm{C}_{\mathrm{e}} 249.32 \mathrm{ppm}$ and $0.3 \mathrm{~g}$ of the adsorbent can absorb $\mathrm{C}_{\mathrm{q}} 0.96 \mathrm{mg} / \mathrm{g}$ and $\mathrm{C}_{\mathrm{e}} 244.26$ ppm while for $0.5 \mathrm{~g}$ the adsorbent able to absorb zinc by $\mathrm{C}_{\mathrm{q}} 2.93 \mathrm{mg} / \mathrm{g}$ with a $\mathrm{C}_{\mathrm{e}}$ value of $220.64 \mathrm{ppm}$ and $0.7 \mathrm{~g}$ of the adsorbent able to absorb more than before that is as much as $\mathrm{C}_{\mathrm{q}} 5.73 \mathrm{mg} / \mathrm{g}$ with $\mathrm{C}_{\mathrm{e}}$ of $169.8 \mathrm{ppm}$. From the overall data seen in figure 3 that shows an increasing graph because the greater mass is given, the adsorbed is greater and also the concentration of zinc used remains the same, namely $250 \mathrm{ppm}$ while the mass of the adsorbent used is greater.

\section{Results of Determination of Time Optimization of Metal Adsorption $\mathrm{Zn}^{+2}$ Zinc Contact by Biomass Chicken Feathers}

The time of contact is very decisive in the adsorption process. Adsorption of ions from a solute will increase if the contact time is longer. Long contact times allow diffusion and attachment of adsorbed solute molecules to take more time to achieve a balanced state of the metal absorption process by the adsorbent ranging from a few minutes to several hours (Khasanah, 2009).

Optimization of contact time of zinc solution with chicken feather biomass was carried out with variations of 20,40 , $60,80,100$, and 120 minutes. The contact time is the time needed for chicken feather biomass to absorb zinc metal, zinc solution is used $250 \mathrm{ppm}$ in $50 \mathrm{~mL}$ with a $\mathrm{pH}$ of solution 6 . The mass of the mass used is 0.7 g. From these data a relationship can be made between contact time with adsorbents and absorbed metal zinc ions as shown in the following figure.

The data in Figure 4 shows the contact time of 20 minutes the absorbed zinc concentration is $\mathrm{C}_{\mathrm{q}} 3.98 \mathrm{mg} / \mathrm{g}$ and $\mathrm{C}_{\mathrm{e}}$ $194.2 \mathrm{ppm}$. in the 40th minute the absorbed concentration decreased to $\mathrm{C}_{\mathrm{q}} 3.86 \mathrm{mg} / \mathrm{g}$ with $\mathrm{C}_{\mathrm{e}} 195.89 \mathrm{ppm}$ and at 60 minutes the absorbed concentration increased to $\mathrm{C}_{\mathrm{q}}$ $5.43 \mathrm{mg} / \mathrm{g}$ and $\mathrm{C}_{\mathrm{e}} 173.9 \mathrm{ppm}$, at the 80th minute it showed $\mathrm{Cq}$ is $5.91 \mathrm{mg} / \mathrm{g}$ and $\mathrm{C}_{\mathrm{e}}$ is $167.2 \mathrm{ppm}$. At 100 minutes and minutes to 120 absorption of zinc concentration decreased $\mathrm{C}_{\mathrm{q}} 5.15 \mathrm{mg} / \mathrm{g}$ with $\mathrm{C}_{\mathrm{e}} 177.9 \mathrm{ppm}$ and $\mathrm{C}_{\mathrm{q}} 5.35 \mathrm{mg} / \mathrm{g}$ with 
$175.08 \mathrm{ppm}$. In this situation caused by the surface adsorption capacity of biomass has saturated and has reached an equilibrium between the concentration of $\mathrm{Zn}$ in biomass and its environment so that absorption at the contact time above 80 minutes and above becomes constant or almost the same (Ni'mah, 2007).

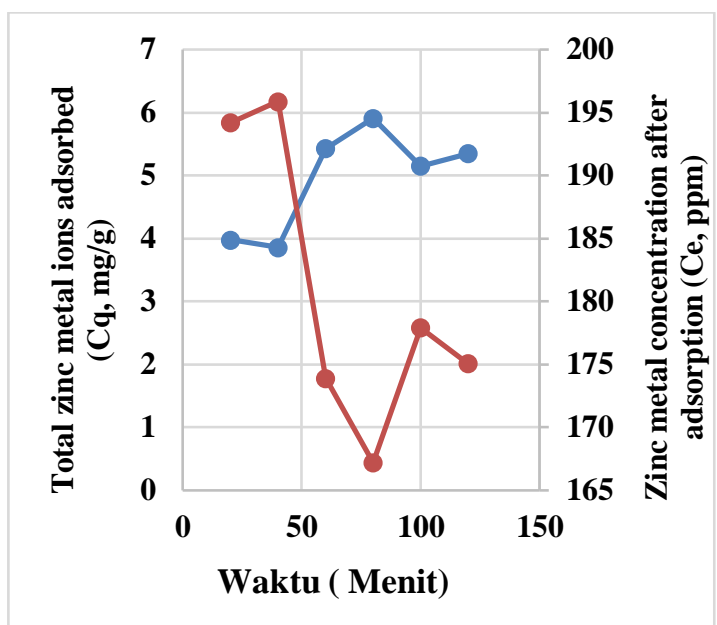

Figure 4. Relationship of Contact Time and Amount of $\mathrm{Zn}^{2+}$ adsorbed by Biomass of Chicken Feathers.

If the surface is covered by a molecular layer, then the adsorption capacity is exhausted (Masduqi, 2000). This shows from the graph pattern above, where after reaching the optimum contact time (80 minutes) $\mathrm{Zn}$ absorbed tends to be constant.

Results of Determination of Optimization of Concentrations of Adsorption of $\mathrm{Zn}^{+2}$ by chicken feather biomass

The concentration of absorbed metal ions is related to the number of active sides found on the surface of the adsorbent, if the number of active sides in the adsorbent is large than the number of metal ions to be absorbed, the absorption efficiency will be constant because there has been saturation on the adsorbent.

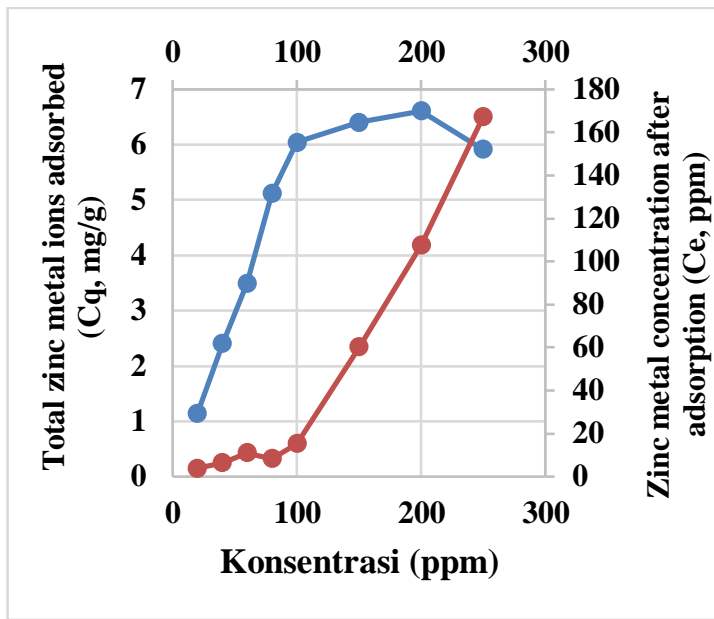

Figure 5. Relationship of initial concentration and amount of $\mathrm{Zn}^{2+}$ adsorbed by Biomass of Chicken Feathers.

The analysis process was carried out at the best conditions of the previous analysis, each at $\mathrm{pH} 6,0.7 \mathrm{~g}$ mass, 80 minutes contact time, and $50 \mathrm{~mL}$ solution volume, with concentrations of 20, 40, 60, 80, 100, 150, 200 and 250 ppm. Based on data from these concentration variations result the relationship between the initial concentration of the solution of zinc with zinc absorption amount, as shown in Figure 5.

From Figure 5 it can be seen that the velocity of the increase in zinc concentration absorbed and the greatest absorption power is at the beginning of absorption at $20 \mathrm{ppm}$ with $\mathrm{C}_{\mathrm{q}} 1.14 \mathrm{mg} / \mathrm{g}$ which previously was $\mathrm{C}_{\mathrm{e}} 3.97$ ppm until the concentration of 100 ppm was $\mathrm{C}_{\mathrm{q}} 6.04$ $\mathrm{mg} / \mathrm{g}$ and $\mathrm{C}_{\mathrm{e}} 15.36 \mathrm{ppm}$, whereas at concentrations higher than $150 \mathrm{ppm}$ the absorption starts constant up to a 
concentration of $250 \mathrm{ppm}$. This happens because at the beginning of absorption, the surface of the adsorbent is still not too much binding to zinc so that the absorption process takes place less effectively. At a concentration of $150 \mathrm{ppm}$ to $250 \mathrm{ppm}$ the concentration is constant around $\mathrm{C}_{\mathrm{e}} 6.5$ $\mathrm{mg} / \mathrm{g}$ with $\mathrm{C}_{\mathrm{q}} 60.34 \mathrm{ppm}$. This is due to the saturated surface adsorption capacity of biomass which has reached an equilibrium between zinc concentration in biomass and its environment, so that optimal absorption occurs at a concentration of $100 \mathrm{ppm}$.

\section{Results of Determination of Adsorption Capacity by Biomass Chicken Feathers}

Table 2 shows the variation in the amount of $\mathrm{Zn}^{2+}$ ions adsorbed as a function of concentration. The higher the concentration, the more $\mathrm{Zn}^{2+}$ ions adsorbed by adsorption of chicken feather biomass.

To determine the capacity of metal adsorption of $\mathrm{Zn}^{2+}$ ions by chicken feather biomass, two isothermal adsorption models were used, namely Langmuir and Freundlich isothermal.

Table 2. Results of Determining the Adsorption Capacity of $\mathrm{Zn}^{2+}$ Ions in Chicken Feather Biomass

\begin{tabular}{cccccc}
\hline $\mathbf{C}_{\mathbf{o}}(\mathbf{p p m})$ & $\mathbf{C}_{\mathbf{e}}(\mathbf{p p m})$ & $\mathbf{q}_{\mathbf{e}}(\mathbf{m g} / \mathbf{g})$ & $\mathbf{C}_{\mathrm{e}} / \mathbf{C}_{\mathbf{q}}$ & $\log \mathbf{C}_{\mathbf{e}}$ & $\log \mathbf{C}_{\mathbf{q}}$ \\
\hline 20 & 3.97 & 1.144 & 3.48 & 0.59 & 0.157 \\
\hline 40 & 6.33 & 2.405 & 2.63 & 0.8 & 0.38 \\
\hline 60 & 11.1 & 3.492 & 3.18 & 1.04 & 0.543 \\
\hline 80 & 8.39 & 5.114 & 1.64 & 0.92 & 0.708 \\
\hline 100 & 15.36 & 6.045 & 2.54 & 1.18 & 0.781 \\
\hline 150 & 60.34 & 6.404 & 9.42 & 1.78 & 0.806 \\
\hline 200 & 107.5 & 6.607 & 16.28 & 2.03 & 0.82 \\
\hline 250 & 167.2 & 5.914 & 28.29 & 2.22 & 0.771 \\
\hline
\end{tabular}

Information :
$\mathrm{C}_{\mathrm{o}}=$ Metal ion concentration before adsorption $(\mathrm{mg} / \mathrm{L})$
$\mathrm{C}_{\mathrm{e}}=$ Metal ion concentration after adsorption $(\mathrm{mg} / \mathrm{L})$
$\mathrm{q}_{\mathrm{e}}=$ Amount of metal ion adsorbed ( $\mathrm{mg} / \mathrm{g}$ )

The isothermal determination of adsorption indicates an association with adsorption capacity, therefore the $\mathrm{C}_{\mathrm{e}}$ curve versus $\mathrm{C}_{\mathrm{e}} / \mathrm{qe}$ is made according to the Langmuir adsorption model (Figure 6) and the curve $\log \mathrm{C}_{\mathrm{e}}$ versus $\log \mathrm{x} / \mathrm{m}$ according to the Freundlich model (Figure 7), by comparing the small line values, the appropriate isothermal adsorption model will be chosen (La Nafie, 2010).
Based on the data on the relationship between Langmuir's isothermal model and Freundlich's isothermal model, the results of the relationship of the absorbed concentration are obtained. 


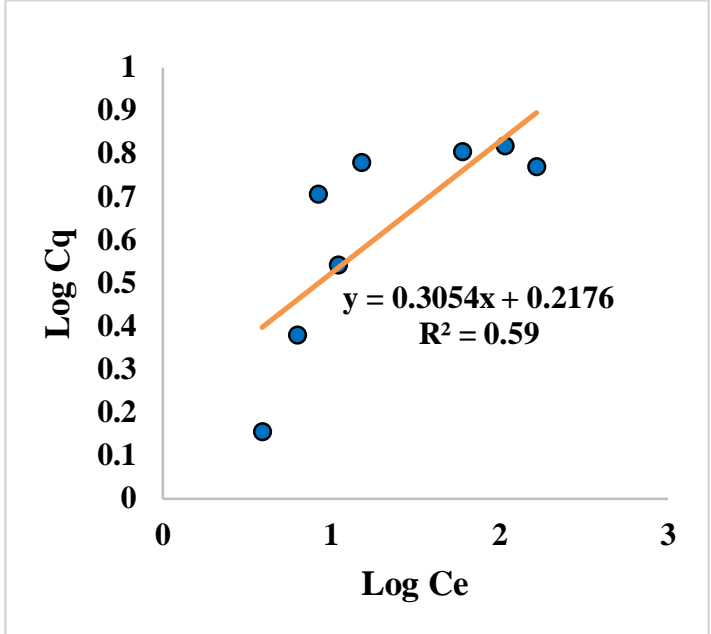

Figure 6. Relationship of Langmuir Isotherm from Adsorption of $\mathrm{Zn}^{2+}$ ions by Biomass Chicken Feathers.

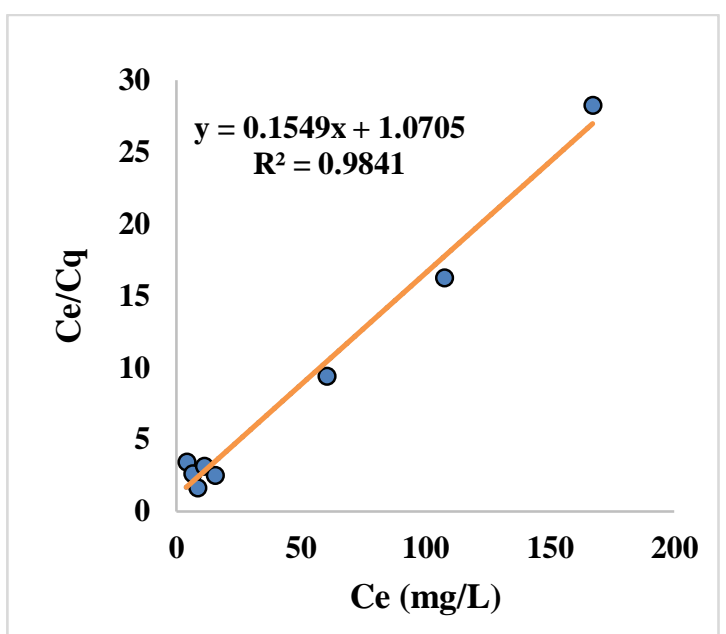

Figure 7. Relationship of Freundlich Isotherm from Adsorption of $\mathrm{Zn}^{2+}$ ions by Biomass Chicken Feathers.

The data in Figure 6 and Figure 7 show that biosorption of $\mathrm{Zn}^{2+}$ ions by chicken feather biomass meets the isothermal Langmuir and Freundlich adsorption, biosorption is more in line with the Langmuir isothermal adsorption where the point tends to show a straight line according to the least squares value where R2 obtained is 0.9841 for chicken feather biomass at optimum condition $\mathrm{pH}$ 6, adsorbent mass $0.7 \mathrm{~g}$, contact time for 80 minutes, so that from the Langmuir isothermal method it can be determined that the adsorption capacity $\left(\mathrm{Q}_{\mathrm{o}}\right)$ obtained is $6.45 \mathrm{mg}$ and $\mathrm{b}$ (adsorption intensity) of $0.16 \mathrm{~L} / \mathrm{mg}$.

\section{CONCLUSION}

Biomass activated with $\mathrm{NaOH}$ and $\mathrm{Na}_{2} \mathrm{SO}_{3}$ chicken feathers can be used as biosorbent of $\mathrm{Zn}$ (II) metal ions with optimum conditions at $\mathrm{pH} 6$, biosorbent mass of 0.7 grams, contact time of 80 minutes and $\mathrm{Zn}^{2+} 100 \mathrm{ppm}$ concentration. The total absorption of $\mathrm{Zn}^{2+}$ ions is $6.04 \mathrm{mg}$ / g. Besides, the isothermal absorption capacity in accordance with the adsorption of chicken feather biomass for $\mathrm{Zn}^{2+}$ ion metal is langmuir isotherm with adsorption capacity value $\left(\mathrm{Q}_{\mathrm{o}}\right)$ obtained at $6.45 \mathrm{mg} / \mathrm{g}$ and $\mathrm{b}$ (Adsorption intensity) of $0.16 \mathrm{~L} / \mathrm{mg}$.

\section{REFRENCES}

Angga, and Evan 2006, Alternative Methods for Overcoming Heavy Metal Pollution, (online), (http://chem-istry.org/?seet=artikel\&test=95, accessed March 27, 2016).

Alberty, R.A., and Daniel, F., 1983. Physical Chemistry (Interpreting: Dr. N.M Surdia), Erlangga, Jakarta.

Atkins, P., W., 1997, Physical Chemistry (Interpreting: Dra. Irma I. K: Erlangga), Jakarta.

Barnosconi, G., 1995, Chemical Technology, First Edition, PT. Pradaya Paramita, Jakarta.

Bertsch, A., and Coello, M., 2005, A biotechnological process for treatment and recycling of poultry feathers as a feed ingredient, Biores Technol, 96 (1): 1703-1708. 
Castellan, G. W., 1982. Physical Chemistry, Second Edition. McGraw Hill, New York.

Breakdown I., H., and Yetis, U., 2001, Biosorption Of Oli (11) and $\mathrm{Pb}$ (11) by Phanaerohaete Chrysosporium From a binary metal system Kinetics, Water SA, 24 (1): 15.

Director General of POM of the Ministry of Health of the Republic of Indonesia, 1995, Indonesian Pharmacopoeia, Ministry of Health of the Republic of Indonesia, Jakarta.

Elfia N., Suciati, W., Nugroho, M., 2002, Effect of Use of Flour and Papain Flour in Broiler Chicken Feed, Research Reports, Animal Science Department, Brawijaya University, Malang.

Gellerstedt, G., 1976, Reaction of Lignin During Sulfite Pulping, Svensk Paperstidn, 79: 537-543.

Giyatmi, Zaenal, K., and Damajati, M., 2008, Decreasing $\mathrm{Cu}, \mathrm{Cr}$, and $\mathrm{Ag}$ Levels in Liquid Waste in the Silver Industry in Kota Gede After Adsorption with Soil Clay from Godean Region, http://journal.sttnbatan.ac .id / wpcontent / upload / 2008/12/5 / Giyatmi99-106.pdf. (access on 10 February 2016).

Haryani, K., 2007, Manufacture of Chitosan from Shrimp Skin to Adsorb Chrome $\left(\mathrm{Cr}^{6+}\right)$ and Copper $(\mathrm{Cu})$, Reactor, 11 (2): 86-90.

Iksan, Muhammad et al., 2011, Thesis Proceedings, Department of Chemistry, Faculty of Mathematics \& Natural Sciences, Ten November Institute of Technology. Surabaya.

Ketaren, 1986, "Food Fat and Oil", UIpress, Jakarta.

Khasanah, 2009, Adsorption of Heavy Metals, Oseana.

Khopkar, S., M., 1984, Basic Concepts of Analytical chemistry (translation), Bombay: Analytical Laboratory
Department of Chemistry Indian institute of Technology, Bombay.

Khosa, Muhammad, M., J., W., 2013, Chemical Modification, Characterization, and Application of Chicken Feathers as Novel Biosorbents, RSC Advance, 3, 20800-20810.

Khumairoh, et al., 2007, Effect of Addition of Ascorbic Acid on Chicken Feathers as an Adsorbent to the Adsorption Ability of Cadmium Metal Ions $\left(\mathrm{Cd}^{2+}\right)$ in Solution, Cheminfo, 1 (1): 369-377.

Kimbal, J., 1983, Biology Fifth Edition Volume 3, Erlangga, Jakarta.

Kim, W., K., Patterson P., H., 2000, Nutritional Value of Enzyme or Sodium Hydroxidetreated Feathers from Dead Hens, Poultry sci. 79: 528-534.

Kunert, J., 2000, Physiology of keratinophilic fungi, Revista Iberoamericana de Micologia, Bilbao: 66-85.

Latifah, R., Nur, et al., 2010, Utilization of $\alpha$-keratin, Chicken Feathers as $\mathrm{Pb}$ Ion Adsorption in textile waste, Alchemy Journal of Chemical Research, 10 (1): 11-21.

Lehninger, A., L., 1990, Basics of Biochemistry, Volume I, Erlangga, Jakarta.

Martell, A., E., and R., D., Hancock, 1996, Metal Complexes in Aqueose Solution, Plenum Press, New York.

Masduqi, A., and Slamet, A., 2000, Process Units: Teaching Modules, Environmental Engineering Department, FTSP ITS, Surabaya.

Moore, G., R., P., Martelli SM., Gandolfo C., Sobral PJ. Do A., Laurindo JB. 2006. Influence of the glycerol concentration on some physical properties of feather keratin films. Food Hydrocolloids 20: 975-982.

Muchtadi, D., 1993, Technique for Evaluating the Nutritional Value of 
Proteins. Postgraduate Program, Bogor Agricultural Institute, Bogor.

Nafie, La, N., et al., 2010, Biosorption of $\mathrm{Pb}$ (II) Metal Ions Using Seagrass Biomass Thallassia hemprichii which is found in Barrang Lompo Island, Marina Chimica Acta, 11 (1): 6-12.

Namasivayam, C., 2001, Uptake of Dyes by a Promosing Locally Available Agriculture Solid Waste, Coir Pith, Was. Manag, 21, 381-387.

Ni'mah, Yatim, L., and Ulfin, Ita, 2007, Decreasing Copper Levels in Solutions Using Biomass Chicken Feathers, Ten November Institute of Technology, Surabaya, Kimindo Deed, 2 (1): 57-66.

Nix, R., 2001, An Introduction of Surface Chemistry, (Online), (http: //www.Chem.Qurm.ac.vk/survace/s cc, accessed February 1, 2018).

Nomanbhay, S., M., And Palanisamy, K., 2005, Removal of Heavy Metal from Industrial Wastewater Using Chitosan Coated Oil Palm Shell Charcoal, J. Elect. Biotechnol, 8, 4353.

Palar, H., 1995, Heavy Metal Pollution and Toxicology, PT Rineka Cipta, Jakarta.

Parry, D., A., D., North ACT, 1998, Hardkeratin intermediate filament chains: the substructure of the $\mathrm{N}$ - and $\mathrm{C}$ terminal domains, the structure and function of the C-terminal domains of type I and type II chains, Struct Biol 122: 67-75.

Pearson, R., G., 1963, Hard and Soft Acids and Bases, J. Am. Soc, 85: 35333539.

Primadhani, S., Y., 2007, Decreasing Copper Levels in Solutions Using Biomass Chicken Feathers with Activation of $0.1 \mathrm{~N}$ Tioglycolic Acid, Thesis, Department of Chemistry, Ten November Institute of Technology Surabaya.
Presland, R., B., Gregg K., Molloy P.L., Morris C.P., Crocker L., A., Rogers, G., E., 1989. Keratin Avian genes. I. A molecular analysis of the structure and expression of a group of feathers of keratin genes, J Mol Biol, 209: 549-559.

Rossa, G., H., E., Reynel, A., A., Bonilla. P., I., Cano. R., C., Velasco, S., and A., 1., Martinez, h, 2008, Recycling of Poultry Feathers for PB Removal from Wastewater: Kinetic and Equilibrium Studies, Engineering and Technology journal: 2 (11): 394402.

Riffel, A., F., S., Lucas, P. Heeb and A. Brandelli. 2003. Characterization of a new keratinolytic bacterium that completely degrades native feather keratin. Archi. Microbiol. 4: 597-635

Setyorini, T., 2006. Optimization of Chromium Metal Absorption in Solutions Using Chicken Feathers Activated with $\mathrm{NaOH} / \mathrm{Na}^{2} \mathrm{~S}$. Department of Chemistry. Ten November Institute of Technology Surabaya.

Suhendrayatna, 2001, Bioremoval Of Heavy Metals Using Microorganisms, a literature study, Presented at the on-Air Biotechnology seminar for Indonesia 21st Century 1-14 February 2001, Forum-PPI Tokyo Institute of Technology.

Sun, P., Liu Z-W, 2009, Particles from Bird Feather: A Novel Application of Ionic Liquid and Waste Resource, Journal of Hazardous Materials, 170, (2); p. 786-790

Tan, T., C., Chia, C., K., Theo, C., K., 1985, Uptake Of Metal by Chemically treated Human Hairs, Water Research, 19 (1): 157-162.

Villarreal, I., A., et al., 2010, Bacth and Column Studies of $\mathrm{Zn} 2+$ Removal from Aqueos Solution using Chicken Feathers as Sorbents, Chemical 
Engineering Journal, 167 (2011):

67-76.

Vogel, 1995, Textbook on Qualitative Macro and Semimicro Inorganic Analysis, Fifth Edition, Part I, PT Kalman Pustaka, Jakarta.

Volesky, B., 1990, Biosorption of Heavy Metals, CRC Press, Boston.

Wagini, R., and Sukaryono, I., D., 2008, Study of Determining the Effectiveness of Screening of Chromium $(\mathrm{Cr})$ and Nickel $(\mathrm{Ni})$ in Eletromagnetic Filtration systems, BSS, 241 (1): 1-15.

Widowati, W., Sastiono, A., Rumampuk, R.J., 2008, Toxic Effects of Metal Pollution Prevention and Control, CV. Andi Offset, Yogyakarta.

Wingrove, A., S., and Caret R. L., 1981, Organic Chemistry, Harper and Row Publisher, New York.

Wirahadikusumah, M., 2001, Biochemistry: Protein, Enzymes and Nucleic Acid, Department of Chemistry, FMIPA ITB, Bandung.

Zerdani, I., M., Faid, and A., Malki., 2004. Feather wastes digestion by new isolates by new isolate strains of Bacillus sp. in Marocco. African $J$. Biotech. 3 (1): 67-70.

Zhang, Helan., 2014, Biorsorption Of Heary Chrome Metal Aqueous Solutions Using Keratin Biomaterials (dissertation), unpublished dissertation. De Qumika Department, Faculty Ed Ciencies, Universitat Autonoma, De Barcelona. 